\title{
IMPLEMENTASI KEBIJAKAN PENANGGULANGAN KEMISKINAN DI KECAMATAN BONMELA KABUPATEN YAHUKIMO
}

\author{
The Implementation of Poverty Reduction Policy in Bonmela District, Yahukimo Regency \\ Yoas Sunyap ${ }^{1}$, Husain Hamka², Syamsul Bahri \\ ${ }^{1}$ Magister Ilmu Administrasi Negara Program Pascasarjana Universitas Bosowa \\ ${ }^{2}$ Program Studi Ilmu Administrasi Negara Program Pascasarjana Universitas Bosowa \\ Email: sunyapy@yahoo.com \\ Diterima: 07 Januari 2020 \\ Dipublikasikan: 05 Juni 2020
}

\begin{abstract}
ABSTRAK
Tujuan penelitian ini untuk menganalisis implementasi kebijakan penangulangan kemiskinan di Kecamatan Bomela Kabupaten Yahukimo yang di laksanakan oleh pemerintah dalam pemenuhan kebutuhan dasar masyarakat. Jika melihat fenomena sampai saat ini masyarakat Papua sebagian masih berada di bawa garis kemiskinan terutama di Kecamatan Bomela Kabupaten Yahukimo seperti kurangnya prasana, tidak ada tranportasi darat, masih kurang sosialisasi tetang hidup layak, masyarakat masih mengandalkan alam untuk memenuhi kebutuhan hidupnya. Penelitian ini menggunakan deskriptif kualitatif. Hasil penelitian menunjukan bahwa, kerangka kebijakan pemberdayaan masyarakat sebagai program dan sebagai cakupan pembangunan memungkinkan mengalami pengembangan dan perluasan ke daerah terjauh hingga terisolir. Hal yang sama juga berlaku untuk program antar proyek yang efektivitas dan efisiensinya dapat diwujudkan.
\end{abstract}

Kata Kunci: Implementasi, Kebijakan, Pemberdayaan, Penanggulangan, Kemiskinan, Bonmela, Yahukimo

\begin{abstract}
This study aims to review, analyze and interpret the implementation of poverty reduction policy in Bomela District, Yahukimo Regency carried out by the government in fulfilling the basic needs of the community. When looking at the phenomenon these days, most Papuans are still under the poverty line, especially in Bomela District, Yahukimo Regency, such as the lack of infrastructure, no land transportation, the lack of socialization about decent living, and people who still rely on nature to fulfill their living needs. The research used qualitative descriptive. The results show that the policy framework of community empowerment as a program and as a part of the development is expected to be extended to remote and isolated areas. It also applies for programs within the projects, which the effectiveness and the efficiency of the activities are expected to be implemented.
\end{abstract}

Keywords: Implementation, Policy, Empowerment, Overcoming, Poverty, Bonmela, Yahukimo

\section{PENDAHULUAN}

Kemiskinan sebagai sebuah realitas sosial, sudah merupakan bagian dari problem sosial setiap negara. Permasalahan kemiskinan tidak bisa diselesaikan seperti permaslahan korupsi. Dari hari kehari permasalahan kemiskinan ini tidak pernah ada angka penurunan dan merupakan hal rumit yang harus diselesaikan oleh pemerintah. Padahal masyarakat di Kecamatan Bomela di Kabupaten Yahukimo memiliki tingkat pertumbuhan ekonomi yang menjanjikan. Namun demikian, realitas di lapangan memperlihatkan bahwa hal tersebut tidak berdampak terhadap peningkatan kesejahteraan masyarakat. Penyebabnya adalah harga bahan pokok yang mengalami kenaikan terus menerus.

Wilayah perdesaan dapat dikategorikan sebagai kantong kemiskinan, termasuk daerah perkotaan. Paling tidak Pemerintah Daerah melakukan atau menemukan cara untuk menanggulangi kemiskinan di daerah pedesaan ini. Dengan program penanggulangan kemiskinan seperti Program keluarga harapan dan lain-lain. Pada wilayah Kecamatan Bomela Kabupaten Yahukimo, kmiskinan masyarakat diakibatkan oleh ketidakpedulian pemerintah dalam mempersiapkan basis minimal kebutuhan masyarakat seperti kesehatan, pendidikan, pelayanan sosial, serta air bersih dan lain-lain.

Selain itu, terkait sumber-sumber pendapatan, terjadi kegagalan akses oleh masyarakat melalui pemerintah daerah dalam rangka pemenuhan kebutuhan secara layak. Adapun akses yang dimaksud seperti kesempatan kerja, dan ketersediaannya. Hal yang sama juga berlaku untuk pemenuhan hak politik masyarakat agar aktif terlibat dalam berbagai pengambilan keputusan atas kebijakan publik untuk pemenuhan kebutuhan dasar.

Tahun 2010 presiden mengeluarkan kebijakan publik yaitu Peraturan Presiden No 13 tahun 2009 tentang koordinasi penanggulangan kemiskinan kemudian dilanjutkan peraturan Presiden No 15 tahun 2010 tentang percepatan penanggulangan kemiskinan, Intruksi Presiden No 1 tahun 2010 tentang percepatan prioritas pembangunan nasional tahun 2010 dan Inpres No 3 Tahun 2010 tentang program pembangunan yang berkeadilan.

Penelitian ini bertujuan untuk menganalisis 
implementasi kebijakan penangulangan kemiskinan di Kecamatan Bomela Kabupaten yang di laksanakan oleh pemerintah dalam pemenuhan kebutuhan dasar masyarakat.

\section{METODE}

Jenis penelitian ini adalah deskriptif kualitatif. Jenis ini merupakan penelitian yang dilakukan terhadap variabel mandiri, dengan tidak membandingkan, atau menghubungkannya dengan variabel lainnya (Sugiyono, 2017). Lokasi penelitian di Kantor Kecamatan Bomela Kabupaten Yahukimo. Informan penelitian ini terdiri atas 1 orang Camat, 1 Sekretaris Camat, 6 orang Pegawai Desa, dan 3 orang masyarakat. Totalnya 11 orang. Informan tersebut dipilih secara sengaja (purposive) karena mereka memiliki informasi yang dibutuhkan sesuai dengan permasalahan penelitian ini. Instrumen Penelitian yaitu Observasi, wawancara, dan dokumentasi. Penelitian ini mempergunakan Data Primer dan Data sekunder. Data primer atau data utama didapatkan melalui wawancara langsung dan terstruktur terhadap informan penelitian. Kepada mereka ditanyakan hal-hal yang terkait masalah penelitian. Data Sekunder atau data pendukung diperoleh dari kajian literatur terkait seperti hasil penelitian jurnal, laporan, buku, dan dokumen di Kecamatan Bomela. Teknik observasi, wawancara, dan dokumentasi merupakan cara yang digunakan untuk mengumpulkan data. Dalam teknik observasi, penulis melakukan pengamatan terhadap kondisi sosial masyarakat di Kecamatan Bomela. Adapun data wawancara dilakukan dengan mewawancarai para informan seperti camat, sekretaris camat, pegawai desa, dan masyarakat setempat. Sedangkan studi dokumentasi dilakukan dengan membaca laporan penelitian, jurnal, dan buku-buku terkait kemudian membandingkannya atau menganalisisnya yang disesuaikan dengan kepentingan penelitian ini.

\section{HASIL DAN PEMBAHASAN}

Pada dasarnya, semua negara di dunia termasuk negara berkembang menghadapi permasalahan tentang kemiskinan. Sebagai problem yang kompleks, faktor yang berpengaruh di dalamnya cukup beragam, mulai dari aspek kesehatan, gender, lingkungan, income, dan masih banyak yang lain. Dalam wawancara dengan Kepala Desa Sombat Kecamatan Bomela Kabupaten Yahukimo tentang angka harapan hidup menunjukkan bahwa sebagai upaya penanganan kemiskinan haruslah integral, serasi, terstruktur, harmonis dan selaras meliputi berbagai pendekatan, fokus, terencana, holistik dan berkelanjutan serta memungkinkan adanya terobosan-terobosan baru. Oleh karenanya selaku Kepala Desa Sombat harus ada upaya yang simultan dengan strategi diantara berbagai sector, wilayah, dan pihak-pihak terkait termasuk penentuan stressing setiap tahunnya, penyempurnaan kelembagaan yang secara khusus menangani kemiskinan pada masyarakat sekarang ini (wawancara 10 April 2019).
Aspek pendidikan ditengarai juga bersebab akibat dengan kemiskinan. Dalam berbagai hasil penelitian dan literatur, keduanya dianggap saling mempengaruhi. Kemiskinan menyebabkan rendahnya pendidikan, dan sisi lainnya rendahnya pendidikan menyebabkan kemiskinan. Hasil penelitian menunjukkan bahwa dalam tingkat pendidikan di Desa Sombat sendiri pemerintah selalu berusaha yang terbaik untuk masyarakat supaya semua anak dapat menyenyam pendidikan. Tetapi yang menjadi kendala kami di Yahukimo sendiri di sebabkan oleh transportasi untuk guru-guru yang datang mengajar selaku pemerintah Desa masih kami perjuangkan untuk mengatasi masalah-masalah yang hadapi sekarang ini untuk anak-anak kedepan yang lebih maju lagi.

Kondisi standar hidup layak dilokasi penelitian menunjukkan standar hidup layak di Desa Sombat masih lebih jauh di bilang layak karna kita masih hidup di garis kemiskinan dengan prasaran yang terbatas. Begitu pula dengan terkait pemenuhan hak dasar, hasil penelitian menunjukkan mewujudkan pembangunan di Kecamatan Bomela berupa sarana dan prasarana kebutuhan masyarakat masih rendah.

Persoalan faktor sosial budaya menjadikan salah satu aspek dalam pengentasan kemiskanan di lokasi penelitian. Ini terlihat pada hasil wawancara dengan informan menunjukkan bahwa kebiasaan masyarakat sangat kuat dengan nilai-nilai lokalnya. Hal inilah yang menyebabkan kondisi masyarakat yang tidak pernah akan berubah. Sebagai pemerintah Desa hidup dengan adat istiadat yang anut dari nenek moyang kami dan tidak bisa di tinggalkan sampai kapanpun.

Dalam wawancara masyarakat yusuf Desa Palamdua Kecamatan Bomela Kabupaten Yahukimo tentang prasarana wilayan beliau menyatakan sebagai berikut:

"Munurut saya di Desa Palamdua prasaran untuk masyarakat masih kurang seperti sekolah, puskesmas dan kebutuhan dasar lainnya masih belum ada yang bisa di nikmati oleh masyarakat setempat karna yang di bangun oleh pemerintah selama ini, masih belum cukup, masyarakat kalau mau pelayanan harus ke Kecamatan dulu baru ada pelayanan, kami sangat membutuhkan prasanan untuk kehidupan yang lebih layak lagi kedepanya". (wawancara 9 juni 2019)

Beberapa aspek kehidupan yang ditangani pemerintah dalam bentuk kebijakan di lokasi penelitian, antara lain:

a. Harapan Hidup.

Salah satu cara dalam menilai kualitas kerja pemerintah terkait kesehatan adalah melakukan evaluasi terhadap pencapaian angka harapan hidup masyarakat. Ini sangat penting karena harapan hidup yang mengalami peningkatan merupakan indikator adanya program yang berjalan dengan baik dan berbasis kepentingan masyarakat.

b. Tingkat Pendidikan.

Hal yang sama juga berlaku untuk aspek pendidikan. Bahkan dalam beberapa tahun terakhir, tingkat 
pendidikan masyarakat di lokasi penelitian tergolong rendah. Tetapi, dalam waktu terakhir hal tersebut telah mengalami pergeseran menjadi lebih bagus. Ini mengindikasikan bahwa ada keseriusan pemerintah dalam mengimplementasikan programnya terkait pelayanan sosial masyarakat.

c. Standar Hidup Layak

Aspek ini sangat penting dalam menilai kinerja pemerintah. Kelayakan hidup yang memenuhi standar merupakan indikator pembangunan baik fisik maupun manusia. Salah satu bentuk kelayakan hidup yang memenuhi standar adalah minimal memenuhi kebutuhan makan sehari-hari 2 kali. Aspek ini tentu berkaitan dengan beberapa variabel, antara lain jenis pekerjaan, tingkat pendapatan. Artinya, bila jenis pekerjaan dan tingkat pendapatan sesuai atau terpenuhi maka dapat dipastikan masyarakat setempat termasuk memiliki standar hidup yang layak.

Kemiskinan yang menjadi problem pemerintah Kecamatan Bomela sedang dalam proses mengatasinya melalui implementasi program-program pembangunan. Program tersebut meliputi hal-hal berikut:

a. Pemenuhan Hak Dasar

Pangan merupakan hak dasar masyarakat lokal yang harus diselesaikan. Ini menjadi krusial ketika diperhadapkan dengan aspek gizi yang belum sesuai standar. Penyebabnya salah satunya terkait dengan daya beli warga yang masih rendah dan keterjangkauan harga beli pangan. Pada saat yang sama pemerintah berhadap dengan ketergantungan masyarakat terhadap beras serta belum adanya diversifikasi.

b. Faktor Sosial Budaya.

Faktor budaya memberi warnga yang cukup besar terciptanya kemiskinan di lokasi penelitian. Budaya konsumtif secara individu dan upacara adat serta keagamaan yang juga berkarakter konsumtif menjadi faktor pendukung hal tersebut.

c. Prasarana Wilayah.

Bervariasinya budaya masyarakat Indonesia berkonsekuensi pada penanganan kemiskinan yang harus juga bervariasi dan bukan sentralistik. Oleh karena itu, pemberdayaan masyarakat juga sebaiknya mempertimbangkan budaya setempat. Ini kemudian turut mempengaruhi aspek sarana dan prasarana wilayah yang dalam pendanaannya sebaiknya berbentuk 'block grant'. Dengan demikian, program pemerintah bisa merata hasilnya dan dinikmati masyarakat setempat.

\section{KESIMPULAN}

Kesimpulan penelitian ini berupa kebijakan Pemerintah di Kabupaten Yahukimo khususnya Kecamatan Bomela telah mengimplementasikan berbagai program secara lintas sektoral dalam menurunkan angka kemiskinan yang bertujuan untuk mewujudkan pertumbuhan ekonomi namun belum signifikan mengentaskan kemiskinan masyarakat. Peran pemerintah Papua khususnya Kabupaten Yahukimo Kecamtan Bomela telah memfokuskan secara prioritas untuk menurunkan jumlah masyarakat miskin di wilayahnya. Program kerja pemerintah Kecamatan Bomela perlu terfokus pada penduduk miskin khususnya yang berpendapatan rendah untuk membangkitkan perekonomian mereka. Selain itu, Pemerintah perlu memperkuat jaringan sosial dan melakukan kerja sama dengan mereka untuk memberdayakan masyarakat miskin.

\section{DAFTAR PUSTAKA}

Dunn, N William. 2000. Pengantar Analisis Kebijakan Publik. (Diterjemahkan oleh: Samodra Wibawa.dkk.) Yogyakarta: Gajah Mada University Press.

Edwards III, George C. 1980. Implementing Public Policy. Washington DC: Congressional Quarterly Press.

Hoogerwerf. 1983. Ilmu pemerintahan. Terjemahan R.L.L. Tobing. Jakarta: Erlangga.

Intruksi Presiden No 1 tahun 2010 tentang percepatan prioritas pembangunan nasional tahun 2010

Islamy, Irfan. 1992. Prinsip-prinsip Perumusan Kebijaksanaan Negara Edisi 2. Jakarta: Bumi Aksara

Keban, Yeremias T. 2004. Enam Dimensi Strategis Administrasi Publik, Konsep, Teori dan Isu. Yogyakarta: Gava Media.

Merilee S., (ed), 1980. Politics and Apolicy Implementation in the Third World, new jersey: Princetown University Press.

Nuggroho. 2006. KebijakanPublik untuk NegaranegaraBerkembang. Jakarta: PT. Elex Media Komputindo.

Nugroho, Riant. D. 2012. Kebijakan Publik, Formulasi, Implementasi dan Evaluasi. Jakarta, Elex Media Computindo. Grindle,

Peraturan Presiden No 13 tahun 2009 tentang koordinasi penanggulangan kemiskinan.

Peraturan Presiden No 15 tahun 2010 tentang percepatan penanggulangan kemiskinan

Solihin. 2008. Corporate Social Responsibility from charity to sustainibility. Salemba Empat, Jakarta.

Subarsono. 2005. Analisis Kebijakan Publik. Yogyakarta: Pustaka Pelajar.

Sugiyono. (2017). Metode Penelitian Kuantitatif, Kualitatif, dan R\&D. Bandung : Alfabeta, CV. 